\title{
Microbiota-Orientated Treatments for Major Depression and Schizophrenia
}

\author{
Guillaume B. Fond ${ }^{1, *}$, Jean-Christophe Lagier ${ }^{2}$, Stéphane Honore ${ }^{1}$, Christophe Lancon ${ }^{1}$, \\ Théo Korchia ${ }^{1}$, Pierre-Louis Sunhary De Verville ${ }^{1}$, Pierre-Michel Llorca ${ }^{3}$, Pascal Auquier ${ }^{1}$, \\ Eric Guedj ${ }^{4}$ and Laurent Boyer ${ }^{1}$ \\ 1 Hôpitaux Universitaires de Marseille, Department de Psychiatrie Universitaire, EA 3279: Aix-Marseille \\ Université, CEReSS-Health Service Research and Quality of Life Center, 27 Boulevard Jean Moulin, \\ 13005 Marseille, France; stephane.honore@ap-hm.fr (S.H.); christophe.lancon@ap-hm.fr (C.L.); \\ theo.korchia@ap-hm.fr (T.K.); deverville.pierrelouis@gmail.com (P.-L.S.D.V.); \\ pascal.auquier@univ-amu.fr (P.A.); laurent.boyer@ap-hm.fr (L.B.) \\ 2 Aix Marseille University, Institut de Recherche pour le Développement, Microbes Evolution Phylogeny and \\ Infection, Assistance Publique Hôpitaux de Marseille, Institut Hospitalo Universitaire Méditerranée \\ Infection, 13005 Marseille, France; JeanChristophe.LAGIER@ap-hm.fr \\ 3 CHU de Clermont-Ferrand, F-63000 Cllermont-Ferrand, France; pmllorca@chu-clermontferrand.fr \\ 4 Aix-Marseille Université, CNRS, Ecole Centrale de Marseille, UMR 7249, Institut Fresnel, Département de \\ médecine nucléaire, CERIMED, Aix-Marseille Université, F-13005 Marseille, France; eric.guedj@ap-hm.fr \\ * Correspondence: guillaume.fond@gmail.com
}

Received: 7 February 2020; Accepted: 2 April 2020; Published: 8 April 2020

check for updates

\begin{abstract}
Background and significance. There is a need to develop new hypothesis-driven treatment for both both major depression (MD) and schizophrenia in which the risk of depression is 5 times higher than the general population. Major depression has been also associated with poor illness outcomes including pain, metabolic disturbances, and less adherence. Conventional antidepressants are partly effective, and $44 \%$ of the subjects remain unremitted under treatment. Improving MD treatment efficacy is thus needed to improve the SZ prognosis. Microbiota-orientated treatments are currently one of the most promising tracks. Method. This work is a systematic review synthetizing data of arguments to develop microbiota-orientated treatments (including fecal microbiota transplantation (FMT)) in major depression and schizophrenia. Results. The effectiveness of probiotic administration in MD constitutes a strong evidence for developing microbiota-orientated treatments. Probiotics have yielded medium-to-large significant effects on depressive symptoms, but it is still unclear if the effect is maintained following probiotic discontinuation. Several factors may limit MD improvement when using probiotics, including the small number of bacterial strains administered in probiotic complementary agents, as well as the presence of a disturbed gut microbiota that probably limits the probiotics' impact. FMT is a safe technique enabling to improve microbiota in several gut disorders. The benefit/risk ratio of FMT has been discussed and has been recently improved by capsule administration. Conclusion. Cleaning up the gut microbiota by transplanting a totally new human gut microbiota in one shot, which is referred to as FMT, is likely to strongly improve the efficacy of microbiota-orientated treatments in MD and schizophrenia and maintain the effect over time. This hypothesis should be tested in future clinical trials.
\end{abstract}

Keywords: psychiatry; schizophrenia; depression; microbiota; transplantation

\section{Introduction}

Major depression (MD) is described as "a global crisis" by the World Health Organization (WHO) [1]. Major depression can affect anyone from young people to seniors, and it is one of the most 
widespread illnesses, often co-existing with other serious illnesses [2]. According to the WHO, MD was ranked as the third leading cause of the global burden of disease in 2004 and will likely have moved to the first place by 2030 [3]. It is now estimated that 350 million people are affected by MD worldwide, which poses a significant health and economic burden to society [4-6]. In 2016, MD was the first source of disability, accounting for 1059 worldwide disability-adjusted life years (DALYs)/100,000 habitants, thereby noticeably preceding ischemic and hemorrhagic stroke (787 and 923 respectively), hypertensive heart disease (242), Alzheimer disease (470), cancers (liver (295), colon (249), breast (208), and HIV (169)) [7]. Major depression was responsible for $48.7 \%$ of all worldwide DALYs related to mental and substance use disorders [7]. This alarming figure is a wakeup call for researchers and should encourage them to address this global non-communicable disease.

Major depression is heterogeneous and improving its treatment may require isolating more specific subgroups in the so-called precision medicine approach. Major depressionv has been identified as a frequent comorbidity of other major psychiatric disorders including schizophrenia (SZ). A half of SZ patients have been identified with MD that has been associated with impaired quality of life which suggests a 5 times higher risk of MD in this population compared to non-SZ individuals. Yet MD remains poorly diagnosed and poorly treated in this population [8-10]. Some studies suggest that MD-SZ may be different from non-SZ MD with lower placebo response and higher impact on functioning [9,11-13]. Major depression in schizophrenia (MD-SZ) has been also associated with other poor illness outcomes including pain, metabolic disturbances, less adherence and lower quality of life $[8,14,15]$. Treating depression is thus needed to improve the SZ prognosis [16]. Conventional antidepressants are partly effective, but $44 \%$ of the subjects remain unremitted under treatment [9]. Yet, funding for research directed to improving diagnosis and treatment of MD-SZ is sadly lacking [17].

Though conventional treatments have improved MD prognosis, they still remain unsatisfactory. The response rate of antidepressants amounts to only $17.7 \%$ in the general population [18]. An explanation for this high rate of non-response and relapses relies on the observation that current pharmacological treatments are primarily based on the monoaminergic hypothesis, without involving the personalized medicine approach. According to this hypothesis, MD is principally due to the fact of a deficit of three neurotransmitters in the brain (i.e., serotonin, norepinephrine, and dopamine). All current antidepressants target serotonin, norepinephrine, or dopamine deficits. The high rate of therapeutic failure in psychiatry can most likely be accounted for by the limitations pertaining to brain-orientated treatments. Current treatments do improve neurotransmitters deficits, yet without addressing the source of these deficits. This may explain the high relapsing rates and chronic illness course.

The key to breaking the deadlock of SZ-MD treatment may be found in the intestinal microbiota [19]. The links between gut microbiota disturbances and brain dysfunction have clearly been demonstrated in rodents. The so-called "gut-brain axis" has already been extensively described in humans with six pathways $[19,20]$ : vagal nerve stimulation; inflammation and cytokine modulation; decreased gut permeability; short-chain fatty acid and neurotransmitter synthesis; nutrient absorption; Hypothalamic-pituitary-adrenal (HPA) stress axis (cortisol) modulation (Figure 1). Moreover, microbiota dysfunctions have been associated with peripheral immune inflammation as well as neuro-inflammation (also called microglia activation) [21]. 


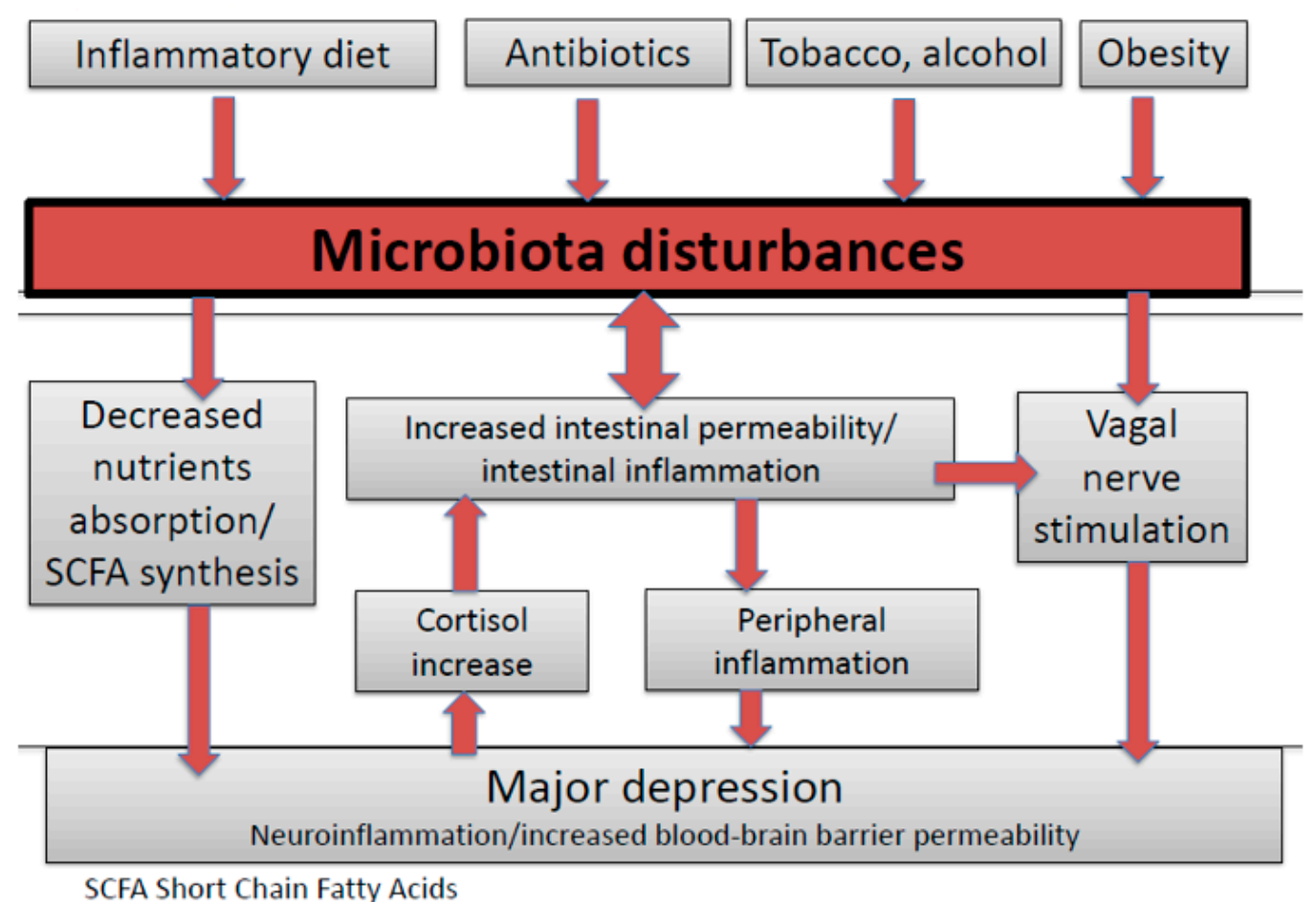

Figure 1. The gut-brain axis in major depression.

Several clues indicate that targeting microbiota may be particularly relevant in schizophrenia (SZ). Schizophrenia patients are treated by antipsychotics that induce gastrointestinal disorders (including constipation) that may impact their gut microbiota. More than one quarter of SZ stabilized outpatients have abdominal obesity, which is a clinical marker of disturbed microbiota, and MD has been found to be the best predictor of rapid high weight gain in SZ [14]. Abnormal bacterial markers have been identified in the blood of SZ patients [22,23]. Emerging data show that about $30 \%$ of SZ people have elevated antigliadin antibodies (AGA) of the IgG type, representing a possible subgroup of schizophrenia patients with increased gut permeability [24]. Also, recent data have shown a high correlation of IgG-mediated antibodies between the periphery and cerebral spinal fluid in schizophrenia but not healthy controls, particularly AGA IgG suggesting that these antibodies may be crossing the blood-brain barrier with resulting neuroinflammation [25]. Schizophrenia has been extensively associated with other abnormal translational markers, suggesting an increased gut permeability in this illness [23,25-29]. More than one in five SZ patients are identified with metabolic syndrome [30], and one-third with chronic low-grade peripheral inflammation [31-34]. This inflammation is a good marker of central inflammation and has also been associated with SZ-MD [35].

Our hypothesis is that replacing the whole microbiota of SZ-MD patients (the so-called fecal microbiota transplantation (FMT)) may improve their mental and physical health, and more specifically their depressive symptoms and quality of life. Schizophrenia combined with MD and/or inflammation may be a target of choice for microbiota-orientated therapies.

The objective was to synthetize current data for testing microbiota-orientated treatments and to explore the benefit/risk ratio of FMT in major depression and schizophrenia.

\section{Methods}

This meta-analysis was based on the Preferred Reporting Items for Systematic reviews and Meta-Analysis (PRISMA) criteria [36] (Figure 1). Medline ${ }^{\circledR}$ database was explored from its inception to March, 22th 2020 without language restriction. The research paradigm was: (depression OR schizophrenia) AND (gut microbiota). The references of each article were also checked. Medline is considered as the database of highest quality level. The associated articles were also explored. 
Scopus ${ }^{\circledR}$ and ScienceDirect ${ }^{\circledR}$ databases were explored with the same strategy (limited to research articles and research reviews and human studies). Two reviewers (GF and LB) decided on eligibility and extracted data from included studies. As this review involved data from published studies, an institutional review board approval was not required.

\subsection{Criteria for Included Studies:}

- Design: Human observational and interventional studies and meta-analyses including human data;

- Exploring the association between microbiota disturbances (or irritable bowel syndrome) and major depression or schizophrenia defined by a DSM or ICD-based diagnostic tool (structured clinical interview) OR assessing the efficacy of a microbiota-orientated therapy (probiotics or fecal microbiota transplantation).

\subsection{Exclusion Criteria:}

- $\quad$ animal studies;

- $\quad$ studies including no individuals with major depression or schizophrenia;

- $\quad$ case reports;

- reviews.

\section{Results}

Fourteen studies were included in the present review.

\subsection{Microbiota-Orientated Therapies and Their Interest for Major Depression}

Irritable bowel syndrome is considered as a paradigmatic microbiota-induced illness. We have published a meta-analysis suggesting that patients with irritable bowel syndrome were at higher risk of major depression [37], confirming the potential causal or bilateral relationship between microbiota disturbances and major depression. Several studies have shown microbiota disturbances in patients with major depression; these disturbances are summarized in Table 1 [38-50]. 
Table 1. Human studies exploring microbiota disturbances in major depression and the interest of microbiota-orientated therapies.

\begin{tabular}{|c|c|c|c|c|}
\hline Author/Date & $\begin{array}{c}\text { Sample Size and Study } \\
\text { Population }(N)\end{array}$ & Techniques & Major Findings & Interpretation \\
\hline Fond et al. 2014 [37] & $\begin{array}{c}10 \text { studies (885 patients and } \\
1384 \mathrm{HCs})\end{array}$ & Meta-analysis & $\begin{array}{c}\text { Patients with IBS had significant higher anxiety and } \\
\text { depression levels than controls (respectively, SMD = } \\
0.76,95 \% \text { CI } 0.47 ; 0.69, p<0.01, \mathrm{I} 2=81.7 \% \text { and SMD }= \\
0.80,95 \% \text { CI } 0.42 ; 1.19, p<0.01, \mathrm{I} 2=90.7 \% \text { ). This } \\
\text { significant difference was confirmed for patients with } \\
\text { IBS-C and -D subtypes for anxiety, and only in IBS-D } \\
\text { patients for depression. }\end{array}$ & $\begin{array}{l}\text { Patients with IBS had significantly } \\
\text { higher levels of anxiety and } \\
\text { depression than HCs. }\end{array}$ \\
\hline Liu et al. 2019 [51] & $\begin{array}{c}29 \text { studies involving } 3088 \\
\text { participants }\end{array}$ & Meta-analysis & $\begin{array}{c}\text { Prebiotics did not differ from placebo for depression } \\
(\mathrm{d}=-0.08, p=0.51) \text { or anxiety }(\mathrm{d}=0.12, p=0.11) \text {. } \\
\text { Probiotics yielded small but significant effects for } \\
\text { depression }(\mathrm{d}=-0.24, p<0.01) \text { and anxiety }(\mathrm{d}=-0.10, \\
p=0.03) \text {. Sample type was a moderator for probiotics } \\
\text { and depression, with a larger effect observed for } \\
\text { clinical/medical samples }(\mathrm{d}=-0.45, p<0.001) \text { than } \\
\text { community ones. This effect increased to } \\
\text { medium-to-large in a preliminary analysis restricted to } \\
\text { psychiatric samples }(\mathrm{d}=-0.73, p<0.001) \text {. }\end{array}$ & $\begin{array}{l}\text { There is general support for } \\
\text { antidepressant and anxiolytic } \\
\text { effects of probiotics, but the pooled } \\
\text { effects were reduced by the paucity } \\
\text { of trials with clinical samples. }\end{array}$ \\
\hline Ng et al. 2019 [49] & 3 studies & Meta-analysis & $\begin{array}{l}\text { No significant difference in schizophrenia symptoms } \\
\text { between the group that received probiotic } \\
\text { supplementation and the placebo group } \\
\text { post-intervention as the standardized mean difference } \\
\text { was - } 0.0884(95 \% \text { CI }-0.380 \text { to } 0.204, p=0.551) \text {. Separate } \\
\text { analyses were performed to investigate the effect of } \\
\text { probiotic supplementation on positive or negative } \\
\text { symptoms of schizophrenia alone. In both instances, } \\
\text { no significant difference was observed as well. }\end{array}$ & $\begin{array}{c}\text { Based on current evidence, limited } \\
\text { inferences can be made regarding } \\
\text { the efficacy of probiotics in } \\
\text { schizophrenia }\end{array}$ \\
\hline Kiecolt-Glaser et al. 2018 [50] & $\begin{array}{c}43(\mathrm{~N}=86) \text { healthy married } \\
\text { couples, ages 24-61 (mean = } \\
38.22)\end{array}$ & $\begin{array}{l}\text { Translocation of bacterial } \\
\text { endotoxin (lipopolysaccharide, } \\
\text { LPS) from the gut microbiota }\end{array}$ & $\begin{array}{l}\text { Participants with more hostile marital interactions had } \\
\text { higher LPS-binding protein (LBP) than those who } \\
\text { were less hostile. Additionally, the combination of } \\
\text { more hostile marital interactions with a mood disorder } \\
\text { history was associated with higher LBP/sCD14 ratios. }\end{array}$ & $\begin{array}{l}\text { The combination of more hostile } \\
\text { marital interactions with a mood } \\
\text { disorder history was associated } \\
\text { with higher LBP/sCD14 ratios. }\end{array}$ \\
\hline
\end{tabular}


Table 1. Cont

\begin{tabular}{|c|c|c|c|c|}
\hline Author/Date & $\begin{array}{c}\text { Sample Size and Study } \\
\text { Population }(N)\end{array}$ & Techniques & Major Findings & Interpretation \\
\hline Chen et al. $2018[44,45]$ & $\begin{array}{l}10 \text { patients (age: } 18-56 \text { years, } \\
\text { five women) who had MDD } \\
\text { and } 10 \text { HCs (age: } 24-65 \\
\text { years, five women) matched } \\
\text { for sex, age, and BMI }\end{array}$ & $\begin{array}{l}\text { Comparative metaproteomics } \\
\text { analysis on the basis of an } \\
\text { isobaric tag for relative and } \\
\text { absolute quantification coupled } \\
\text { with tandem mass spectrometry }\end{array}$ & $\begin{array}{l}279 \text { significantly differentiated bacterial proteins }(p< \\
0.05) \text { were detected and used for further bioinformatic } \\
\text { analysis. According to phylogenetic analysis, } \\
\text { statistically significant differences were observed for } \\
\text { four phyla: Bacteroidetes, Proteobacteria, Firmicutes, } \\
\text { Actinobacteria }(p<0.05 \text {, for each). Abundances of } 16 \\
\text { bacterial families were significantly different between } \\
\text { the MDD and healthy controls ( } p<0.05) \text {. Cluster of } \\
\text { Orthologous Groups analysis and Kyoto Encyclopedia } \\
\text { of Genes and Genomes pathway analysis showed that } \\
\text { disordered metabolic pathways of bacterial proteins } \\
\text { were mainly involved in glucose metabolism and } \\
\text { amino acid metabolism. }\end{array}$ & $\begin{array}{l}\text { Fecal microbiota signatures were } \\
\text { altered significantly in MDD } \\
\text { patients. }\end{array}$ \\
\hline Peter et al. 2018 [38] & $\begin{array}{l}48 \text { patients with IBS (Rome } \\
\text { III criteria, M (SD) age }=42 \\
\text { (15) years, } 35 \text { female, } 25 \\
\text { diarrhea-dominant, } 5 \\
\text { constipation-dominant, and } \\
18 \text { alternating-type IBS) }\end{array}$ & $\begin{array}{l}\text { alpha and beta diversity, } \\
\text { correlational analyses of } \\
\text { bacterial abundance and } \\
\text { comparisons among subgroups } \\
\text { defined by thresholds of } \\
\text { psychological and IBS symptom } \\
\text { variables, and machine learning } \\
\text { to identify bacterial patterns } \\
\text { corresponding with } \\
\text { psychological distress. }\end{array}$ & $\begin{array}{l}\text { Thirty-one patients (65\%) showed elevated } \\
\text { psychological distress, } 22(31 \%) \text { anxiety, and } 10 \\
\text { depression }(21 \%) \text {. Microbial beta diversity was } \\
\text { significantly associated with distress and depression } \\
\text { (q }=0.036 \text { each, q values are p values false discovery } \\
\text { rate-corrected for multiple testing). Depression was } \\
\text { negatively associated with Lachnospiraceae abundance } \\
\text { (Spearman's } \varrho=-0.58, \mathrm{q}=0.018) \text {. Patients exceeding } \\
\text { thresholds of distress, anxiety, depression, and stress } \\
\text { perception showed significantly higher abundances of } \\
\text { Proteobacteria ( } \mathrm{q}=0.020-0.036) \text {. Patients with anxiety } \\
\text { were characterized by elevated Bacteroidaceae (q }= \\
\text { 0.036). A signature of } 148 \text { unclassified species } \\
\text { accounting for 3.9\% of total bacterial abundance } \\
\text { co-varied systematically with the presence of } \\
\text { psychological distress. }\end{array}$ & $\begin{array}{l}\text { Psychological variables significantly } \\
\text { segregated gut microbial features, } \\
\text { underscoring the role of } \\
\text { brain-gut-microbiota interaction in } \\
\text { IBS. A microbial signature } \\
\text { corresponding with psychological } \\
\text { distress was identified. }\end{array}$ \\
\hline
\end{tabular}


Table 1. Cont

\begin{tabular}{|c|c|c|c|c|}
\hline Author/Date & $\begin{array}{l}\text { Sample Size and Study } \\
\text { Population }(N)\end{array}$ & Techniques & Major Findings & Interpretation \\
\hline Kelly et al. 2016 [39] & $\begin{array}{c}34 \text { MDD patients and } 33 \\
\text { matched HCs }\end{array}$ & 16s rRNA sequencing & $\begin{array}{l}\text { Chao1 richness ( } \mathrm{U}=424, p=0.005) \text {, total observed } \\
\text { species ( } \mathrm{U}=441, p=0.002) \text { and phylogenetic diversity } \\
\text { (U }=447.5, p=0.001 \text { ) were decreased in the depressed } \\
\text { group. was no difference in Shannon diversity ( } \mathrm{U}= \\
\text { 350, } p=0.197) \text {. Significant differences in beta diversity } \\
\text { between the healthy and depressed groups } \\
\text { (Bray-Curtis }(p=0.014), \text { unweighted unifrac }(p= \\
0.002 \text { and weighted unifrac }(p=0.018) \text { were unable to } \\
\text { separate groups according to PCoA analysis). The } \\
\text { difference of the global microbiota composition from } \\
\text { the } 16 \mathrm{~S} \text { rRNA data of the depressed and control } \\
\text { groups was assessed by ordination. Statistics based on } \\
\text { random permutations of the redundancy analysis } \\
\text { (RDA) showed that the depressed group is } \\
\text { significantly separated at genus level }(p=0.03 \text { ) from } \\
\text { the control group. No difference on intestinal } \\
\text { permeability, short chain fatty acids, fecal metabolites } \\
\text { has been reported. }\end{array}$ & $\begin{array}{l}\text { Depression is associated with } \\
\text { decreased gut microbiota richness } \\
\text { and diversity }\end{array}$ \\
\hline Lin et al. 2017 [48] & $N=10 \mathrm{MDD}$ & $\begin{array}{l}\text { V3-V4 region of the } 16 \mathrm{~S} \text { rRNA } \\
\text { gene was extracted from the } \\
\text { fecal microbial communities in } \\
\text { MDD patients, PCR amplified } \\
\text { and sequenced on the Illumina } \\
\text { Miseq platform }\end{array}$ & $\begin{array}{l}\text { More phylum Firmicutes, less Bacteroidetes, and more } \\
\text { genus Prevotella, Klebsiella, Streptococcus and } \\
\text { Clostridium XI were found in MDD patients. The } \\
\text { changes of the proportion of Prevotella and Klebsiella } \\
\text { were consistent with Hamilton depression rating scale. }\end{array}$ & $\begin{array}{l}\text { Prevotella and Klebsiella } \\
\text { proportion in fecal microbial } \\
\text { communities should be concerned } \\
\text { in the diagnosis and therapeutic } \\
\text { monitoring of MDD in future. }\end{array}$ \\
\hline Liu et al. 2016 [42] & $\begin{array}{c}N=100 \\
40 \text { with } \\
\text { diarrhea-predominant IBS } \\
\text { (IBS-D), } 15 \text { with depression, } \\
25 \text { with comorbidities of } \\
\text { depression and IBS patients, } \\
\text { and } 20 \text { healthy individuals } \\
\text { (controls) }\end{array}$ & $\begin{array}{l}\text { Colonic mucosal inflammation } \\
\text { was assayed by } \\
\text { immunohistochemical analyses } \\
\text { of sigmoid biopsied tissues }\end{array}$ & $\begin{array}{l}\text { Fecal microbiota signatures were similar between } \\
\text { patients with IBS-D and } \\
\text { depression presented, in that they were less diverse } \\
\text { than samples from controls and had similar } \\
\text { abundances of alterations. were characterized by high } \\
\text { proportions of Bacteroides (Type I), Prevotella (Type II), } \\
\text { or non-dominant microbiota (Type III). } \\
\text { Most patients with IBS-D or depression had Type I or } \\
\text { Type II profiles (IBS-D had } 85 \% \text { Type I and Type II, } \\
\text { depression had } 80 \% \text { Type I and Type II profiles). }\end{array}$ & $\begin{array}{l}\text { Patients with IBS-D and depression } \\
\text { have similar alterations in fecal } \\
\text { microbiota; these might be related } \\
\text { to the pathogenesis of these } \\
\text { disorders. } 3 \text { microbial profiles in } \\
\text { patients could indicate different } \\
\text { subtypes of IBS and depression or } \\
\text { be used as diagnostic biomarkers }\end{array}$ \\
\hline
\end{tabular}


Table 1. Cont

\begin{tabular}{|c|c|c|c|c|}
\hline Author/Date & $\begin{array}{l}\text { Sample Size and Study } \\
\text { Population }(N)\end{array}$ & Techniques & Major Findings & Interpretation \\
\hline Jiang et al. 2015 [43] & $\begin{array}{l}46 \text { patients with depression } \\
(29 \text { active-MDD and } 17 \\
\text { responded-MDD) and } 30 \\
\text { healthy controls (HCs). }\end{array}$ & $\begin{array}{l}\text { high-throughput } \\
\text { pyrosequencing }\end{array}$ & $\begin{array}{l}\text { Increased fecal bacterial } \alpha \text {-diversity was found in the } \\
\text { active-MDD (a-MDD) vs. the HC group but not in the } \\
\text { responded-MDD (R-MDD) vs. the HC group. } \\
\text { Bacteroidetes, Proteobacteria, and Actinobacteria strongly } \\
\text { increased in level, whereas that of Firmicutes was } \\
\text { significantly reduced in the A-MDD and R-MDD } \\
\text { groups compared with the HC group. } \\
\text { Despite profound interindividual variability, levels of } \\
\text { several predominant genera were significantly } \\
\text { different between the MDD and HC groups. Most } \\
\text { notably, the MDD groups had increased levels of } \\
\text { Enterobacteriaceae and Alistipes but reduced levels of } \\
\text { Faecalibacterium. A negative correlation was observed } \\
\text { between Faecalibacterium and the severity of } \\
\text { depressive symptoms. }\end{array}$ & $\begin{array}{l}\text { These findings enable a better } \\
\text { understanding of changes in the fecal } \\
\text { microbiota composition in such } \\
\text { patients, showing either a } \\
\text { predominance of some potentially } \\
\text { harmful bacterial groups or a } \\
\text { reduction in beneficial bacterial } \\
\text { genera. }\end{array}$ \\
\hline Kleiman et al. 2015 [41] & $\begin{array}{l}\text { Inpatients with anorexia } \\
\text { nervosa at admission (T1; } n \\
=16) \text { and discharge (T2; } n= \\
\text { 10). Patients with anorexia } \\
\text { nervosa were compared } \\
\text { with healthy individuals } \\
\text { who participated in a } \\
\text { previous study (HCs). }\end{array}$ & $\begin{array}{l}\text { Genomic DNA was isolated } \\
\text { from stool samples, and } \\
\text { bacterial composition was } \\
\text { characterized by } 454 \\
\text { pyrosequencing of the } 16 \mathrm{~S} \\
\text { rRNA gene. }\end{array}$ & $\begin{array}{l}\text { Significant changes emerged between T1 and T2 in } \\
\text { taxa abundance and beta (between-sample) diversity } \\
\text { of patients with anorexia nervosa. Patients with } \\
\text { anorexia nervosa had significantly lower alpha } \\
\text { (within-sample) diversity than did HCs at both T1 ( } p= \\
\text { 0.0001) and T2 ( } p=0.016 \text { ), and differences in taxa } \\
\text { abundance were found between anorexia nervosa } \\
\text { patients and HCs. }\end{array}$ & $\begin{array}{c}\text { There was evidence of an intestinal } \\
\text { dysbiosis in anorexia nervosa and an } \\
\text { association between mood and the } \\
\text { enteric microbiota in this patient } \\
\text { population }\end{array}$ \\
\hline Madan et al. 2020 [47] & $\begin{array}{l}\text { Adult MDD inpatients } \\
\qquad(\mathrm{N}=111)\end{array}$ & $\begin{array}{l}\text { 16S rRNA gene sequencing and } \\
\text { whole genome shotgun } \\
\text { sequencing }\end{array}$ & $\begin{array}{l}\text { Depression and anxiety severity shortly after } \\
\text { admission were negatively associated with bacterial } \\
\text { richness and alpha diversity. Additional analyses } \\
\text { revealed a number of bacterial taxa associated with } \\
\text { depression and anxiety severity. Gut microbiota } \\
\text { richness and alpha diversity early in the course of } \\
\text { hospitalization was a significant predictor of } \\
\text { depression remission at discharge. }\end{array}$ & $\begin{array}{l}\text { There is a gut microbiota relationship } \\
\text { with symptom severity among MDD } \\
\text { inpatients as well as a relationship to } \\
\text { remission of depression } \\
\text { post-treatment. }\end{array}$ \\
\hline
\end{tabular}


Table 1. Cont

\begin{tabular}{|c|c|c|c|c|}
\hline Author/Date & $\begin{array}{l}\text { Sample Size and Study } \\
\text { Population }(N)\end{array}$ & Techniques & Major Findings & Interpretation \\
\hline Mason et al. 2020 [46] & $\begin{array}{c}\mathrm{N}=70 \text { (60 psychiatric } \\
\text { subjects; MDD (comorbid } \\
\text { with anxiety), } n=38, \\
\text { anxiety only, } n=8, \mathrm{MDD} \\
\text { only without anxiety, } n=14, \\
\text { HCs } n=10\end{array}$ & $\begin{array}{l}\text { Quantitative } \mathrm{PCR} \text { and } 16 \mathrm{~S} \\
\text { rRNA sequencing }\end{array}$ & $\begin{array}{l}\text { Altered microbiota correlated with pre-defined clinical } \\
\text { presentation, with Bacteroides }(p=0.011) \text { and the } \\
\text { Clostridium leptum subgroup }(p=0.023) \text { significantly } \\
\text { different between clinical categories. Cluster analysis } \\
\text { of the total sample using weighted Unifrac } \beta \text {-diversity } \\
\text { of the gut microbiota identified two different clusters } \\
\text { defined by differences in bacterial distribution. Cluster } \\
2 \text { had higher Bacteroides }(p=0.006) \text {, and much reduced } \\
\text { presence of Clostridales }(p<0.001) \text { compared to Cluster } \\
1 . \text { Bifidobacterium }(p=0.0173) \text { was also reduced in } \\
\text { Cluster } 2 \text { compared to Cluster } 1 \text {. When evaluated for } \\
\text { clinical charateristics, anhedonia scores in Cluster } 2 \\
\text { were higher than in Cluster } 1 \text {. }\end{array}$ & $\begin{array}{l}\text { Reduced or absent Clostridia was } \\
\text { consistently seen in those with } \\
\text { depression, independent of the } \\
\text { presence of anxiety. Conversely, } \\
\text { reduced Bacteroides may be more } \\
\text { associated with the presence of } \\
\text { anxiety, independent of the } \\
\text { presence of depression. }\end{array}$ \\
\hline $\begin{array}{l}\text { Naseribafrouei } \\
\text { et al., } 2014 \text { [40] }\end{array}$ & $\begin{array}{c}\mathrm{N}=55 \text { (37 MDD, and } 18 \\
\text { HCs })\end{array}$ & $\begin{array}{l}\text { Illumina deep sequencing of } 16 \mathrm{~S} \\
\text { rRNA gene amplicons }\end{array}$ & $\begin{array}{l}\text { The order Bacteroidales showed an overrepresentation } \\
(p=0.05) \text {, while the family Lachnospiraceae showed an } \\
\text { underrepresentation }(p=0.02) \text { of Operational } \\
\text { Taxonomic Units associated with depression. }\end{array}$ & $\begin{array}{l}\text { Several correlations were found } \\
\text { between depression and fecal } \\
\text { microbiota. }\end{array}$ \\
\hline
\end{tabular}

MDD: Major depressive disorder. IBS: irritable bowel syndrome. HCs: Healthy controls. BMI: body mass index. 
The effectiveness of probiotic administration in MD constitutes a strong evidence for developing microbiota-orientated treatments in this indication. Probiotics have yielded medium-to-large significant effects in the setting of depression $(\mathrm{d}=-0.73(95 \% \mathrm{CI}=-1.02-0.44))$ in a recent meta-analysis [51]. Approximately half of all existing studies were published over the past two years, reflecting the rapidly growing interest in this area. At the time of this submission, 29 studies involving 3088 participants were published so far. Duration of probiotic administration across trials ranged from 8 days to 45 weeks, whereas it is still unclear if the effect is maintained following probiotic discontinuation.

Two factors may limit MD improvement when probiotics are administered: (1) the small number of bacterial strains administered in probiotic complementary agents (often only one to five bacterial strains including Lactobacilli, either alone or in combination with Bifidobacterium), and (2) the presence of a disturbed gut microbiota that limits probiotics' efficacy (the so-called gut microbiota "resilience"). Cleaning up the gut microbiota and transplanting a totally new human gut microbiota in one shot (the so-called fecal microbiota transplantation) would thus strongly improve the effect size.

\subsection{Fecal Microbiota Transplantation's Effectiveness in Non-Psychiatric Diseases}

If MD is actually associated with microbiota dysfunctions, replacing disturbed microbiota by a healthy one appears to be one of the most promising approach to improve MD [52]. FMT has been described as "the ultimate probiotic" as it provides an entire microbiome to the recipient. This therapy delivers a much greater number and diversity of bacteria than any current commercially available preparation. In the past decade, there has been a heightened interest in the use of this therapy [53], predominantly driven by increasing rates of recurrent Clostridium difficile infection [54-56].

This procedure was proven associated with $87 \%-100 \%$ clinical resolution of recurrent or refractory C. difficile infections [56-60]. This impressive success rate is presumably due to the ability of the transplanted bacteria to recolonize/occupy the missing components/niches of the normal intestinal microbiota thus removing the microbial niche that $C$. difficile would otherwise exploit.

In addition to this main application, FMT has demonstrated promising results in other diseases as well such as ulcerative colitis [61,62] or inflammatory bowel diseases [63].

\subsection{Fecal Microbiota Transplantation's Safety in Non-Psychiatric Diseases}

No serious adverse event related to FMT has been reported in the literature. In a recent review, the commonest FMT-attributable adverse event was abdominal discomfort, which was reported in 19 publications [64].

There is a potential to transmit infection via contaminated donor stool. The donor stool must therefore undergo microscopy and culture for potential bacterial pathogens, microscopy for ova, cysts and parasites as well as viral studies and C. difficile toxin analysis. Blood testing to exclude HIV, Hepatitis B and C and syphilis must be undertaken.

Changes in fecal microbiota have been found in patients with a number gastrointestinal and extra-intestinal diseases. Changes in the microbiome of patients with inflammatory bowel diseases and irritable bowel syndrome are well documented in the literature [65].

There have also been associations between various bowel flora, obesity, and the metabolic syndrome. The association has not been documented as causal, and it appears probably related to the diet consumed by these subjects. It would, however, be prudent to exclude donors with the metabolic syndrome.

SZ patients are already treated with antipsychotics, antidepressants, and other psychotropic drugs that have many side-effects (including sedation, weight gain, neurological disorders, diarrhea, and constipation), the FMT appears as a safe treatment in comparison of the standard treatment for SZ and MD. The risk-benefit balance seems favorable. 


\subsection{Oral Capsules Administration: An Improvement for Fecal Microbiota Transplantation Safety}

The oral capsule administration form has proven an equal effectiveness [66] and will prevent the adverse event due to the conventional colonoscopy-delivered upper and lower gastrointestinal routes of FMT, especially bowel perforation over-sedation, aspiration, bleeding, and splenic laceration $[67,68]$. Some studies reported patient deaths due to the underlying disease, where the patient has not responded to the FMT. Our clinical experience and our 5 years collaboration with patients' associations has also shown to us that an important rate of the patients and their relatives are waiting for innovating treatments targeting new pathways, with a better tolerance than antipsychotics. In France, the microbiota hypothesis is very popular and highly broadcasted in the media.

\section{Conclusions}

Cleaning up the gut microbiota by transplanting a totally new human gut microbiota in one shot, which is referred to as FMT, is likely to strongly improve the efficacy and maintains the effect over time. The safety and acceptability have been recently improved with capsule administration that should be evaluated in future clinical trials for the treatment of major depression and schizophrenia. Future trials should confirm the effectiveness and identify responder profiles in the context of personalized medicine.

Author Contributions: Conceptualization, G.B.F., J.-C.L. and L.B.; methodology, G.B.F.; resources, G.B.F.; data curation, G.B.F.; writing — original draft preparation, G.B.F., J.-C.L. and L.B.; writing—review and editing, G.B.F., J.-C.L., L.B., S.H., C.L., T.K., P.-L.S.D.V., P.-M.L., P.A., E.G.; supervision L.B.; funding acquisition, G.B.F. and L.B. All authors have read and agreed to the published version of the manuscript.

Funding: This work was funded by Hôpitaux Universitaires de Marseille (HUM), grant number AORC-2018.

Conflicts of Interest: The authors declare no conflict of interest.

\section{References}

1. WHO. Depression: A Global Crisis. World Mental Health Day, October 10 2012; World Federation for Mental Health: Occoquan, VA, USA, 2012.

2. Fond, G.; Lancon, C.; Auquier, P.; Boyer, L. Prevalence of major depression in France in the general population and in specific populations from 2000 to 2018: A systematic review of the literature. Presse Med. Paris Fr. 1983 2019, 48, 365-375.

3. Fond, G.; Masson, M.; Auquier, P.; Da Fonseca, D.; Lançon, C.; Llorca, P.-M.; Boyer, L. The key role of psychiatry in the development of French health-related sustainable development goals. L'Encephale 2019, 45, 99-100. [CrossRef] [PubMed]

4. Sobocki, P.; Jönsson, B.; Angst, J.; Rehnberg, C. Cost of depression in Europe. J. Ment. Health Policy Econ. 2006, 9, 87-98. [PubMed]

5. Greenberg, P.E.; Fournier, A.-A.; Sisitsky, T.; Pike, C.T.; Kessler, R.C. The economic burden of adults with major depressive disorder in the United States (2005 and 2010). J. Clin. Psychiatry 2015, 76, 155-162. [CrossRef] [PubMed]

6. Fond, G.; Masson, M.; Lançon, C.; Auquier, P.; Boyer, L. Updating of the French recommendations for the first-line treatment of major depression. L'Encephale 2019, 45, 457-458. [CrossRef]

7. Hay, S.I.; Abajobir, A.A.; Abate, K.H.; Abbafati, C.; Abbas, K.M.; Abd-Allah, F.; Abdulkader, R.S.; Abdulle, A.M.; Abebo, T.A.; Abera, S.F.; et al. GBD 2016 DALYs and HALE Collaborators Global, regional, and national disability-adjusted life-years (DALYs) for 333 diseases and injuries and healthy life expectancy (HALE) for 195 countries and territories, 1990-2016: A systematic analysis for the global burden of disease study 2016. Lancet Lond. Engl. 2017, 390, 1260-1344.

8. Andrianarisoa, M.; Boyer, L.; Godin, O.; Brunel, L.; Bulzacka, E.; Aouizerate, B.; Berna, F.; Capdevielle, D.; Dorey, J.M.; Dubertret, C.; et al. Childhood trauma, depression and negative symptoms are independently associated with impaired quality of life in schizophrenia. Results from the national FACE-SZ cohort. Schizophr. Res. 2017, 185, 173-181. [CrossRef] 
9. Fond, G.; Boyer, L.; Berna, F.; Godin, O.; Bulzacka, E.; Andrianarisoa, M.; Brunel, L.; Aouizerate, B.; Capdevielle, D.; Chereau, I.; et al. Remission of depression in patients with schizophrenia and comorbid major depressive disorder: Results from the FACE-SZ cohort. Br. J. Psychiatry 2018, 213, 464-470. [CrossRef]

10. Alessandrini, M.; Lançon, C.; Fond, G.; Faget-Agius, C.; Richieri, R.; Faugere, M.; Metairie, E.; Boucekine, M.; Llorca, P.-M.; Auquier, P.; et al. A structural equation modelling approach to explore the determinants of quality of life in schizophrenia. Schizophr. Res. 2016, 171, 27-34. [CrossRef]

11. Fond, G.; Godin, O.; Dumontaud, M.; Faget, C.; Schürhoff, F.; Berna, F.; Aouizerate, B.; Capdevielle, D.; Chereau, I.; D'Amato, T.; et al. Sexual dysfunctions are associated with major depression, chronic inflammation and anticholinergic consumption in the real-world schizophrenia FACE-SZ national cohort. Prog. Neuropsychopharmacol. Biol. Psychiatry 2019, 94, 109654. [CrossRef]

12. Kucerova, J.; Babinska, Z.; Horska, K.; Kotolova, H. The common pathophysiology underlying the metabolic syndrome, schizophrenia and depression. A review. Biomed. Pap. Med. Fac. Univ. Palacký Olomouc Czechoslov. 2015, 159, 208-214. [CrossRef] [PubMed]

13. Gregory, A.; Mallikarjun, P.; Upthegrove, R. Treatment of depression in schizophrenia: Systematic review and meta-analysis. Br. J. Psychiatry J. Ment. Sci. 2017, 211, 198-204. [CrossRef] [PubMed]

14. Godin, O.; Leboyer, M.; Schürhoff, F.; Boyer, L.; Andrianarisoa, M.; Brunel, L.; Bulzacka, E.; Aouizerate, B.; Berna, F.; Capdevielle, D.; et al. Predictors of rapid high weight gain in schizophrenia: Longitudinal analysis of the French FACE-SZ cohort. J. Psychiatr. Res. 2017, 94, 62-69. [CrossRef] [PubMed]

15. Fond, G.; Boyer, L.; Andrianarisoa, M.; Godin, O.; Bulzacka, E.; Berna, F.; Brunel, L.; Coulon, N.; Aouizerate, B.; Capdevielle, D.; et al. Self-reported pain in patients with schizophrenia. Results from the national first-step FACE-SZ cohort. Prog. Neuropsychopharmacol. Biol. Psychiatry 2018, 85, 62-68. [CrossRef]

16. Nakajima, S.; Takeuchi, H.; Fervaha, G.; Plitman, E.; Chung, J.K.; Caravaggio, F.; Iwata, Y.; Mihashi, Y.; Gerretsen, P.; Remington, G.; et al. Comparative efficacy between clozapine and other atypical antipsychotics on depressive symptoms in patients with schizophrenia: Analysis of the CATIE phase 2E data. Schizophr. Res. 2015, 161, 429-433. [CrossRef]

17. Wykes, T.; Haro, J.M.; Belli, S.R.; Obradors-Tarragó, C.; Arango, C.; Ayuso-Mateos, J.L.; Bitter, I.; Brunn, M.; Chevreul, K.; Demotes-Mainard, J.; et al. Mental health research priorities for Europe. Lancet Psychiatry 2015, 2, 1036-1042. [CrossRef]

18. Cipriani, A.; Furukawa, T.A.; Salanti, G.; Chaimani, A.; Atkinson, L.Z.; Ogawa, Y.; Leucht, S.; Ruhe, H.G.; Turner, E.H.; Higgins, J.P.T.; et al. Comparative efficacy and acceptability of 21 antidepressant drugs for the acute treatment of adults with major depressive disorder: A systematic review and network meta-analysis. Lancet Lond. Engl. 2018, 391, 1357-1366. [CrossRef]

19. Zhu, X.; Han, Y.; Du, J.; Liu, R.; Jin, K.; Yi, W. Microbiota-gut-brain axis and the central nervous system. Oncotarget 2017, 8, 53829-53838. [CrossRef]

20. Fond, G.; Chevalier, G.; Eberl, G.; Leboyer, M. The potential role of microbiota in major psychiatric disorders: Mechanisms, preclinical data, gastro-intestinal comorbidities and therapeutic options. Presse Med. Paris Fr. 1983 2016, 45, 7-19.

21. Campos, A.C.; Rocha, N.P.; Nicoli, J.R.; Vieira, L.Q.; Teixeira, M.M.; Teixeira, A.L. Absence of gut microbiota influences lipopolysaccharide-induced behavioral changes in mice. Behav. Brain Res. 2016, 312, 186-194. [CrossRef]

22. Severance, E.G.; Prandovszky, E.; Castiglione, J.; Yolken, R.H. Gastroenterology issues in schizophrenia: Why the gut matters. Curr. Psychiatry Rep. 2015, 17, 27. [CrossRef] [PubMed]

23. Severance, E.G.; Gressitt, K.L.; Stallings, C.R.; Origoni, A.E.; Khushalani, S.; Leweke, F.M.; Dickerson, F.B.; Yolken, R.H. Discordant patterns of bacterial translocation markers and implications for innate immune imbalances in schizophrenia. Schizophr. Res. 2013, 148, 130-137. [CrossRef] [PubMed]

24. Fond, G.; Lançon, C.; Auquier, P.; Boyer, L. C-reactive protein as a peripheral biomarker in schizophrenia. An updated systematic review. Front. Psychiatry 2018, 9, 392. [CrossRef] [PubMed]

25. Rowland, L.M.; Demyanovich, H.K.; Wijtenburg, S.A.; Eaton, W.W.; Rodriguez, K.; Gaston, F.; Cihakova, D.; Talor, M.V.; Liu, F.; McMahon, R.R.; et al. Antigliadin antibodies (AGA IgG) are related to neurochemistry in schizophrenia. Front. Psychiatry 2017, 8, 104. [CrossRef]

26. Rook, G.A.W.; Raison, C.L.; Lowry, C.A. Microbiota, immunoregulatory old friends and psychiatric disorders. Adv. Exp. Med. Biol. 2014, 817, 319-356. 
27. Rodrigues-Amorim, D.; Rivera-Baltanás, T.; Regueiro, B.; Spuch, C.; de Las Heras, M.E.; Vázquez-Noguerol Méndez, R.; Nieto-Araujo, M.; Barreiro-Villar, C.; Olivares, J.M.; Agís-Balboa, R.C. The role of the gut microbiota in schizophrenia: Current and future perspectives. World J. Biol. Psychiatry Off. J. World Fed. Soc. Biol. Psychiatry 2018, 19, 571-585. [CrossRef]

28. Schwarz, E.; Maukonen, J.; Hyytiäinen, T.; Kieseppä, T.; Orešič, M.; Sabunciyan, S.; Mantere, O.; Saarela, M.; Yolken, R.; Suvisaari, J. Analysis of microbiota in first episode psychosis identifies preliminary associations with symptom severity and treatment response. Schizophr. Res. 2018, 192, 398-403. [CrossRef]

29. Shen, Y.; Xu, J.; Li, Z.; Huang, Y.; Yuan, Y.; Wang, J.; Zhang, M.; Hu, S.; Liang, Y. Analysis of gut microbiota diversity and auxiliary diagnosis as a biomarker in patients with schizophrenia: A cross-sectional study. Schizophr. Res. 2018, 197, 470-477. [CrossRef]

30. Godin, O.; Leboyer, M.; Gaman, A.; Aouizerate, B.; Berna, F.; Brunel, L.; Capdevielle, D.; Chereau, I.; Dorey, J.M.; Dubertret, C.; et al. Metabolic syndrome, abdominal obesity and hyperuricemia in schizophrenia: Results from the FACE-SZ cohort. Schizophr. Res. 2015, 168, 388-394. [CrossRef]

31. Fond, G.; Godin, O.; Boyer, L.; Berna, F.; Andrianarisoa, M.; Coulon, N.; Brunel, L.; Bulzacka, E.; Aouizerate, B.; Capdevielle, D.; et al. Chronic low-grade peripheral inflammation is associated with ultra resistant schizophrenia. Results from the FACE-SZ cohort. Eur. Arch. Psychiatry Clin. Neurosci. 2018, 269, 985-992. [CrossRef]

32. Fond, G.; Resseguier, N.; Schürhoff, F.; Godin, O.; Andrianarisoa, M.; Brunel, L.; Bulzacka, E.; Aouizerate, B.; Berna, F.; Capdevielle, D.; et al. Relationships between low-grade peripheral inflammation and psychotropic drugs in schizophrenia: Results from the national FACE-SZ cohort. Eur. Arch. Psychiatry Clin. Neurosci. 2017, 268, 541-553. [CrossRef] [PubMed]

33. Fond, G.; Berna, F.; Andrianarisoa, M.; Godin, O.; Leboyer, M.; Brunel, L.; Aouizerate, B.; Capdevielle, D.; Chereau, I.; D'Amato, T.; et al. Chronic low-grade peripheral inflammation is associated with severe nicotine dependence in schizophrenia: Results from the national multicentric FACE-SZ cohort. Eur. Arch. Psychiatry Clin. Neurosci. 2017, 267, 465-472. [CrossRef] [PubMed]

34. Fond, G.; Godin, O.; Brunel, L.; Aouizerate, B.; Berna, F.; Bulzacka, E.; Capdevielle, D.; Chereau, I.; Dorey, J.M.; Dubertret, C.; et al. Peripheral sub-inflammation is associated with antidepressant consumption in schizophrenia. Results from the multi-center FACE-SZ data set. J. Affect. Disord. 2016, 191, $209-215$. [CrossRef] [PubMed]

35. Faugere, M.; Micoulaud-Franchi, J.-A.; Faget-Agius, C.; Lançon, C.; Cermolacce, M.; Richieri, R. High C-reactive protein levels are associated with depressive symptoms in schizophrenia. J. Affect. Disord. 2018, 225, 671-675. [CrossRef] [PubMed]

36. Moher, D.; Liberati, A.; Tetzlaff, J.; Altman, D.G. PRISMA Group Preferred reporting items for systematic reviews and meta-analyses: The PRISMA statement. Br. Med. J. 2009, 339, b2535. [CrossRef] [PubMed]

37. Fond, G.; Loundou, A.; Hamdani, N.; Boukouaci, W.; Dargel, A.; Oliveira, J.; Roger, M.; Tamouza, R.; Leboyer, M.; Boyer, L. Anxiety and depression comorbidities in irritable bowel syndrome (IBS): A systematic review and meta-analysis. Eur. Arch. Psychiatry Clin. Neurosci. 2014, 264, 651-660. [CrossRef] [PubMed]

38. Peter, J.; Fournier, C.; Durdevic, M.; Knoblich, L.; Keip, B.; Dejaco, C.; Trauner, M.; Moser, G. A Microbial signature of psychological distress in irritable bowel syndrome. Psychosom. Med. 2018, 80, 698-709. [CrossRef]

39. Kelly, J.R.; Borre, Y.; O’ Brien, C.; Patterson, E.; El Aidy, S.; Deane, J.; Kennedy, P.J.; Beers, S.; Scott, K.; Moloney, G.; et al. Transferring the blues: Depression-associated gut microbiota induces neurobehavioural changes in the rat. J. Psychiatr. Res. 2016, 82, 109-118. [CrossRef]

40. Naseribafrouei, A.; Hestad, K.; Avershina, E.; Sekelja, M.; Linløkken, A.; Wilson, R.; Rudi, K. Correlation between the human fecal microbiota and depression. Neurogastroenterol. Motil. Off. J. Eur. Gastrointest. Motil. Soc. 2014, 26, 1155-1162. [CrossRef]

41. Kleiman, S.C.; Watson, H.J.; Bulik-Sullivan, E.C.; Huh, E.Y.; Tarantino, L.M.; Bulik, C.M.; Carroll, I.M. The intestinal microbiota in acute anorexia nervosa and during renourishment: Relationship to depression, anxiety, and eating disorder psychopathology. Psychosom. Med. 2015, 77, 969-981. [CrossRef]

42. Liu, Y.; Zhang, L.; Wang, X.; Wang, Z.; Zhang, J.; Jiang, R.; Wang, X.; Wang, K.; Liu, Z.; Xia, Z.; et al. Similar fecal microbiota signatures in patients with diarrhea-predominant irritable bowel syndrome and patients with depression. Clin. Gastroenterol. Hepatol. Off. Clin. Pract. J. Am. Gastroenterol. Assoc. 2016, 14, 1602-1611. [CrossRef] [PubMed] 
43. Jiang, H.; Ling, Z.; Zhang, Y.; Mao, H.; Ma, Z.; Yin, Y.; Wang, W.; Tang, W.; Tan, Z.; Shi, J.; et al. Altered fecal microbiota composition in patients with major depressive disorder. Brain. Behav. Immun. 2015, 48, 186-194. [CrossRef] [PubMed]

44. Chen, J.-J.; Zheng, P.; Liu, Y.-Y.; Zhong, X.-G.; Wang, H.-Y.; Guo, Y.-J.; Xie, P. Sex differences in gut microbiota in patients with major depressive disorder. Neuropsychiatr. Dis. Treat. 2018, 14, 647-655. [CrossRef] [PubMed]

45. Chen, Z.; Li, J.; Gui, S.; Zhou, C.; Chen, J.; Yang, C.; Hu, Z.; Wang, H.; Zhong, X.; Zeng, L.; et al. Comparative metaproteomics analysis shows altered fecal microbiota signatures in patients with major depressive disorder. Neuroreport 2018, 29, 417-425. [CrossRef] [PubMed]

46. Mason, B.L.; Li, Q.; Minhajuddin, A.; Czysz, A.H.; Coughlin, L.A.; Hussain, S.K.; Koh, A.Y.; Trivedi, M.H. Reduced anti-inflammatory gut microbiota are associated with depression and anhedonia. J. Affect. Disord. 2020, 266, 394-401. [CrossRef] [PubMed]

47. Madan, A.; Thompson, D.; Fowler, J.C.; Ajami, N.J.; Salas, R.; Frueh, B.C.; Bradshaw, M.R.; Weinstein, B.L.; Oldham, J.M.; Petrosino, J.F. The gut microbiota is associated with psychiatric symptom severity and treatment outcome among individuals with serious mental illness. J. Affect. Disord. 2020, 264, 98-106. [CrossRef]

48. Lin, P.; Ding, B.; Feng, C.; Yin, S.; Zhang, T.; Qi, X.; Lv, H.; Guo, X.; Dong, K.; Zhu, Y.; et al. Prevotella and Klebsiella proportions in fecal microbial communities are potential characteristic parameters for patients with major depressive disorder. J. Affect. Disord. 2017, 207, 300-304. [CrossRef]

49. Ng, Q.X.; Soh, A.Y.S.; Venkatanarayanan, N.; Ho, C.Y.X.; Lim, D.Y.; Yeo, W.-S. A systematic review of the effect of probiotic supplementation on schizophrenia symptoms. Neuropsychobiology 2019, 78, 1-6. [CrossRef]

50. Kiecolt-Glaser, J.K.; Wilson, S.J.; Bailey, M.L.; Andridge, R.; Peng, J.; Jaremka, L.M.; Fagundes, C.P.; Malarkey, W.B.; Laskowski, B.; Belury, M.A. Marital distress, depression, and a leaky gut: Translocation of bacterial endotoxin as a pathway to inflammation. Psychoneuroendocrinology 2018, 98, 52-60. [CrossRef]

51. Liu, R.T.; Walsh, R.F.L.; Sheehan, A.E. Prebiotics and probiotics for depression and anxiety: A systematic review and meta-analysis of controlled clinical trials. Neurosci. Biobehav. Rev. 2019, 102, 13-23. [CrossRef]

52. Lagier, J.-C.; Raoult, D. Fecal microbiota transplantation: Indications and perspectives. Med. Sci. M/S 2016, 32, 991-997.

53. Lagier, J.-C.; Million, M.; Raoult, D. Bouillabaisse or fish soup: The Limitations of meta-analysis confronted to the inconsistency of fecal microbiota transplantation studies. Clin. Infect. Dis. Off. Publ. Infect. Dis. Soc. Am. 2019. [CrossRef] [PubMed]

54. Kump, P.K.; Krause, R.; Allerberger, F.; Högenauer, C. Faecal microbiota transplantation-the Austrian approach. Clin. Microbiol. Infect. Off. Publ. Eur. Soc. Clin. Microbiol. Infect. Dis. 2014, 20, 1106-1111. [CrossRef] [PubMed]

55. Cui, B.; Feng, Q.; Wang, H.; Wang, M.; Peng, Z.; Li, P.; Huang, G.; Liu, Z.; Wu, P.; Fan, Z.; et al. Fecal microbiota transplantation through mid-gut for refractory Crohn's disease: Safety, feasibility, and efficacy trial results. J. Gastroenterol. Hepatol. 2015, 30, 51-58. [CrossRef]

56. Hocquart, M.; Lagier, J.-C.; Cassir, N.; Saidani, N.; Eldin, C.; Kerbaj, J.; Delord, M.; Valles, C.; Brouqui, P.; Raoult, D.; et al. Early fecal microbiota transplantation improves survival in severe clostridium difficile infections. Clin. Infect. Dis. Off. Publ. Infect. Dis. Soc. Am. 2018, 66, 645-650. [CrossRef]

57. Van Nood, E.; Vrieze, A.; Nieuwdorp, M.; Fuentes, S.; Zoetendal, E.G.; de Vos, W.M.; Visser, C.E.; Kuijper, E.J.; Bartelsman, J.F.W.M.; Tijssen, J.G.P.; et al. Duodenal infusion of donor feces for recurrent Clostridium difficile. N. Engl. J. Med. 2013, 368, 407-415. [CrossRef]

58. Austin, M.; Mellow, M.; Tierney, W.M. Fecal microbiota transplantation in the treatment of Clostridium difficile infections. Am. J. Med. 2014, 127, 479-483. [CrossRef]

59. Cammarota, G.; Masucci, L.; Ianiro, G.; Bibbò, S.; Dinoi, G.; Costamagna, G.; Sanguinetti, M.; Gasbarrini, A. Randomised clinical trial: Faecal microbiota transplantation by colonoscopy vs. vancomycin for the treatment of recurrent Clostridium difficile infection. Aliment. Pharmacol. Ther. 2015, 41, 835-843. [CrossRef]

60. Li, Y.-T.; Cai, H.-F.; Wang, Z.-H.; Xu, J.; Fang, J.-Y. Systematic review with meta-analysis: Long-term outcomes of faecal microbiota transplantation for Clostridium difficile infection. Aliment. Pharmacol. Ther. 2016, 43, 445-457. [CrossRef]

61. Paramsothy, S.; Kamm, M.A.; Kaakoush, N.O.; Walsh, A.J.; van den Bogaerde, J.; Samuel, D.; Leong, R.W.L.; Connor, S.; Ng, W.; Paramsothy, R.; et al. Multidonor intensive faecal microbiota transplantation for active ulcerative colitis: A randomised placebo-controlled trial. Lancet 2017, 389, 1218-1228. [CrossRef] 
62. Costello, S.P.; Hughes, P.A.; Waters, O.; Bryant, R.V.; Vincent, A.D.; Blatchford, P.; Katsikeros, R.; Makanyanga, J.; Campaniello, M.A.; Mavrangelos, C.; et al. Effect of fecal microbiota transplantation on 8-week remission in patients with ulcerative colitis: A randomized clinical trial. JAMA 2019, 321, 156-164. [CrossRef] [PubMed]

63. Johnsen, P.H.; Hilpüsch, F.; Cavanagh, J.P.; Leikanger, I.S.; Kolstad, C.; Valle, P.C.; Goll, R. Faecal microbiota transplantation versus placebo for moderate-to-severe irritable bowel syndrome: A double-blind, randomised, placebo-controlled, parallel-group, single-centre trial. Lancet Gastroenterol. Hepatol. 2018, 3, 17-24. [CrossRef]

64. Wang, S.; Xu, M.; Wang, W.; Cao, X.; Piao, M.; Khan, S.; Yan, F.; Cao, H.; Wang, B. Systematic review: Adverse events of fecal microbiota transplantation. PLoS ONE 2016, 11, e0161174. [CrossRef] [PubMed]

65. Flint, H.J. Obesity and the gut microbiota. J. Clin. Gastroenterol. 2011, 45, S128-S132. [CrossRef] [PubMed]

66. Rao, K.; Young, V.B.; Malani, P.N. Capsules for fecal microbiota transplantation in recurrent clostridium difficile Infection: The new way forward or a tough pill to swallow? JAMA 2017, 318, 1979-1980. [CrossRef]

67. Kao, D.; Roach, B.; Silva, M.; Beck, P.; Rioux, K.; Kaplan, G.G.; Chang, H.-J.; Coward, S.; Goodman, K.J.; $\mathrm{Xu}, \mathrm{H}$; ; et al. Effect of oral capsule- vs colonoscopy-delivered fecal microbiota transplantation on recurrent clostridium difficile infection: A randomized clinical trial. JAMA 2017, 318, 1985-1993. [CrossRef]

68. Staley, C.; Hamilton, M.J.; Vaughn, B.P.; Graiziger, C.T.; Newman, K.M.; Kabage, A.J.; Sadowsky, M.J.; Khoruts, A. Successful resolution of recurrent clostridium difficile infection using freeze-dried, encapsulated fecal microbiota; pragmatic cohort study. Am. J. Gastroenterol. 2017, 112, 940-947. [CrossRef]

(C) 2020 by the authors. Licensee MDPI, Basel, Switzerland. This article is an open access article distributed under the terms and conditions of the Creative Commons Attribution (CC BY) license (http://creativecommons.org/licenses/by/4.0/). 